Llwyd Cwta (S. 171) is the more suitable variety, and useful information gained from practical experience in its cultivation during the previous season is to be found in the leaflet. Farmers growing the Aberystwyth strains are particularly requested to inform the Plant Breeding Station of the behaviour of the varieties in question, as such reports are of great value to those engaged on the selection work.

\section{Conservation of Natural Resources}

IN the United States, strenuous efforts are being made by the Government, through its Forest Service, National Park Service, Soil Conservation Service, Tennessee Valley Authority and other agencies to remedy the disastrous effects of years of neglect and exploitation. Many voluntary organizations co. operate. In "Conservation in the Education Pro. gram" (Bulletin No. 4 of 1937), the Commissioner of Education presents an account of the progress made in introducing into school curricula instruction designed to awaken an appreciation of the importance to the community of conservation of natural resources and the duty of the individual citizen in relation thereto. Such instruction is conveyed in general in connexion with regularly established school subjects such as nature-study, elementary science, the social sciences, particularly geography; but in at least one State "Protection and Conservation of Life, Property and Natural Resources" is one of a number of social functions selected as bases for organizing instruction according to the theory that things should be learnt in relation to the ways in which they will be used. In addition to outlining existing practices, the bulletin contains a detailed prospectus prepared in the Curriculum Construction Laboratory of Teachers College, Columbia University, of a course of instruction on the theme "How is Man trying to Conserve his Natural Resources".

\section{The History of Science}

WE have received vol. 3 , part 1 , of Osiris, the journal devoted to the history of science and edited by G. Sarton. This part is dedicated to Prof. E. O. von Lippmann, a biographical notice (with portrait) and a bibliography being contributed by J. R. Partington. Several of the articles deal with the history of mathematics and astronomy; there is also one on Sir Charles Blagden by F. H. Getman and one on Leeuwenhoek by A. W. Meyer, and L. B. Simpson contributes an account of the medicine of the Conquistadores based on a sixteenth century manuscript. The mathematical papers deal with linear and quadratic equations (Kloyda), the calculus of variations (Carathéodory), and the graphical representation of statistical data (Funkhouser). Other interesting papers make up a noteworthy issue.

\section{Announcements}

Sir John Anderson, the National Government candidate, has been elected Member of Parliament in the Scottish Universities seat which became vacant on the death of Mr. Ramsay MacDonald.
The Kelvin Medal Award Committee, on which are represented eight of the most important engineering institutions, has awarded the Kelvin Medal for 1938 to Sir J. J. Thomson, Master of Trinity College, Cambridge, in recognition of the eminent services he has rendered to engineering science. The presentation will be made by Lord Rayleigh at the Institution of Civil Engineers on May 3.

The first award of the James Alfred Ewing Medal of the Institution of Civil Engineers has been made to Mr. C. S. Franklin, research expert, formerly chief of the Independent Research Department, of the Marconi Company. Mr. Franklin is known chiefly for his researches in connexion with the Marconi beam system. The Bayliss Prize of the Institution has been awarded to Mr. R. Kerridge.

The following have been elected honorary members of the Institution of Civil Engineers : H.M. the King of the Belgians; H.R.H. the Crown Prince of Sweden; Sir Robert Elliott-Cooper, senior pastpresident of the Institution; and Sir Frank Smith, secretary of the Department of Scientific and In. dustrial Research.

Sir Albert Seward, formerly professor of botany in the University of Cambridge, has recently been elected a trustee of the British Museum.

Prof. E. S. Goodrich, Linacre professor of zoology and comparative anatomy in the University of Oxford, has been elected a member of the Section of Zoology of the Royal Swedish Academy of Science, Stogkholm.

ThE twenty-ninth Congress of the German Radiological Society will be held on July 4-7 at Munich under the presidency of Dr. G. A. Weltz. Further information can be obtained from Prof. Karl Frik, Brückerallee 22, Berlin.

ThE fifth International Congress of Cell Research will be held at Zurich on August 7-13, when the following subjects will be discussed : epithelium in cultures and in the organism, structure of chromosomes, mechanism of mitosis, cancer cell and normal cell, experimental cell investigation, and investigation of viruses. Further information can be obtained from Das Anatomische Institut, Plattenstrasse 9, Zurich 7.

THE annual Malaria Control Course for Laymen (engineers, planters, etc.) will be held at the Ross Institute of Tropical Hygiene commencing on June 27, 1938. The course will be under Sir Malcolm Watson, director of the Institute. It is designed for planters and mining engineers, but it will be of interest to all (including missionaries) who are proceeding to the tropics. Further information can be obtained from the Organizing Secretary, Ross Institute of Tropical Hygiene, Keppel Street (Gower Street), Isondon, W.C.l. 